\title{
Collective Approach to Complex Food System Issues, the Case of The Ohio State University
}

Julie Fox

\begin{abstract}
Urban universities are uniquely positioned to make powerful and lasting contributions to the grand challenge of food security. To better understand the various dimensions related to the university's role in food systems, this case study explores intentional linkages, significant developments, natural tensions, and emerging impacts at the Ohio State University. Discoveries from this analysis can guide urban university decision makers as they confront complex food system challenges.
\end{abstract}

\section{Keywords}

Food security, Sustainability, Engaged scholarship, University stewardship

\section{Introduction}

Urban university leaders are positioned to inspire and invest in collaborative solutions to emerging food system challenges. Food fulfills nutritional needs, but it also embodies social, cultural, economic, political, and environmental significance (Mcgirr \& Batterbury, 2016). Food system issues, such as production, supply, marketing, distribution, access, health, consumption, and disposal of wastes, span the contexts of local and global; rural and urban; conventional and alternative (Koc, 1999; Lang \& Heasman, 2015; Pothukuchi \& Kaufman, 1999).

Food systems are a priority of the Ohio State University (OSU). As one of America's largest and most comprehensive urban universities, OSU's annual budget supports six campuses across the state, Extension offices in all 88 counties, international collaborations, 18 colleges and schools, more than 33,000 employees, and 65,000 students. The university's collective attention on food extends through all levels of the institution. This includes the board of trustees and university senate, down to faculty, staff, students, alumni, donors, volunteers, and other community members. Their conjoint efforts involve them in (a) food system teaching and learning; (b) research and innovation; (c) outreach and engagement; and (d) resource stewardship (see Figure 1). 


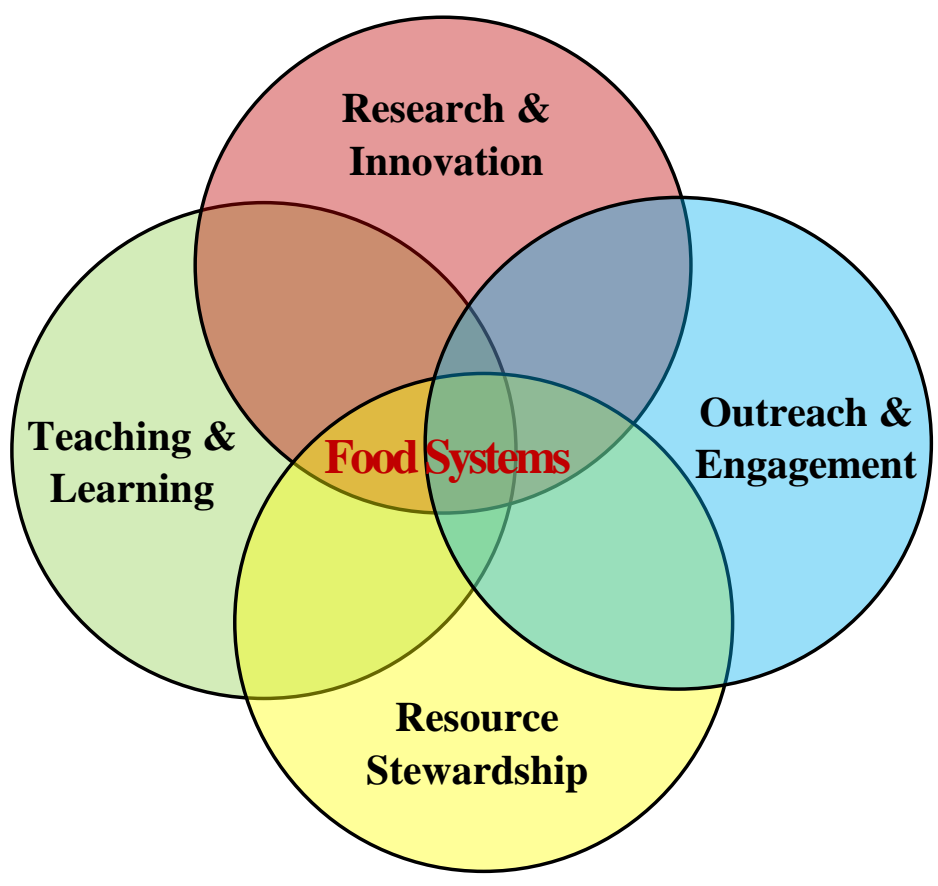

Figure 1. OSU's collective approach to food systems aligns with the University's mission. Navigating through the many aspects related to food systems with a university this size requires tremendous collaboration. As one of seven focal points, the OSU food initiative directly involves academic units, dining services, advancement, and multiple centers and research institutes. Individually, these resources make direct impact. Collectively, they address the most pressing needs, such as sustainable food systems. Despite many independent and collaborative hungerfighting efforts and an Ohio agricultural industry worth $\$ 100$ billion, food security remains a significant issue in the state. Food security is a condition in which all community residents obtain a safe, culturally acceptable, nutritionally adequate diet through a sustainable food system that maximizes community self-reliance, social justice, and democratic decision-making (Hamm \& Bellows, 2003). Over the next decade, OSU plans to invest nearly $\$ 125$ million in food security, combatting this critical challenge from all disciplinary fronts as an integral element of OSU President Drake's 2020 Vision for the university. "We can solve critical issues of our time," stated Drake. "Our collective efforts can and will transform lives." During the timeframe of this study, food security and food systems have moved from key topics integrated into many projects to primary drivers of unified strategic initiatives. "Wicked problems" such as food security, require a more collaborative, integrative, transparent, and inclusive model (Fauvel \& Lake, 2015).

Many urban universities focus on multiple food system factors. For example, Pothukuchi and Molnar (2015) examined sustainable food systems at urban public universities, with a summary of curriculum, food gardens, farmers markets, dining services, and other indicators. Barlett (2011) compared small, medium, and large university campus sustainable food projects as demonstrated through food purchasing goals, academic programs, direct marketing, and experiential learning. Relevant literature reviews concentrate on food system components, such 
as urban agriculture impacts (Golden, 2013). Additional studies have been published in university reports and diverse journals centered on agriculture, social science, planning, policy, economic, and geography. This study (a) draws upon previous approaches; (b) expands to include elements such as advancement, cluster hires, and the role of university governance; and (c) examines mission-driven strategic investments related to teaching, research, engagement, and stewardship. The intent was to better understand the strategic shift of urban universities to a more collective approach to complex food system issues.

\section{Methods}

Case studies allow researchers to investigate contemporary complex phenomenon within real-life context (Creswell, 2013; Yin, 2011) and is often used in organizational research (Hartley 1994). The case study described here explores how OSU approached food system interests that contributed to the university's vision as a model of a 21 st century public, land grant, research, urban, and community engaged institution. To understand this case in its distinctiveness, the researcher's approach was interpretive and analytical, rather than solely descriptive (Merriam, 1988; Stake, 1995). This approach was selected to illuminate contextual aspects of the situation to gather both agreed upon and diverse views (Lauckner, Paterson, \& Krupa, 2012). Sources of data were collected through examination of the literature, document reviews, and observations during the five-year period of 2012-16. Search indexes included ProQuest, EBSCO Host, Web of Science, and Google Scholar. Nested Boolean searches included "urban university and food systems" and "university food system teaching, research, engagement, or stewardship." The researcher used the internet archive, the Wayback Machine to investigate historical website content (Hackett \& Parmanto, 2005; Murphy, Hashim, \& O’Connor; 2007; Thelwall \& Wilkinson, 2003). Documents were evaluated and organized based on contributions in one or more components of teaching and learning; research and innovation; outreach and engagement; and resource stewardship. Because the intention was not to isolate these perspectives, the researcher also noted the relationships connecting them. Limitations of the study could be addressed through future research using multiple methods and a longer period to study of OSU's six campuses, 15 colleges, 105 departments, and more than 220 centers and institutes.

\section{Food System Teaching and Learning}

A focus on food systems is integrated into teaching and learning across multiple disciplines through a variety of degree programs, courses, studio assignments, capstone projects, internships, education abroad experiences, special events, and other engaged learning options. Each college, school, and center brings distinct specialization. Increasingly, units are working collectively to advance learning through broader perspective. Unique aspects at OSU include a two-year Associate degree option at the Agriculture Technical Institute that can lead to undergraduate and graduate degrees at the university's five other locations, experiential learning on a 261 -acre urban farm on the Columbus campus, and collaboration of multiple units to support a course aligned with the university's sustainability goals (see Table 1). 
Table 1

OSU Examples of Food System Teaching and Student Learning

\begin{tabular}{|c|c|}
\hline Unit & Experiential Learning \\
\hline $\begin{array}{l}\text { College of Food, } \\
\text { Agricultural, and } \\
\text { Environmental Sciences }\end{array}$ & $\begin{array}{l}\text { Various food-related undergraduate and graduate degrees } \\
\text { Agricultural Technical Institute, Associate of Science } \\
\text { Agroecosystems Management Program, endowed by the } \\
\text { W. K. Kellogg Foundation } \\
\text { Waterman Farm ( } 261 \text { acre farm on prime campus real estate) }\end{array}$ \\
\hline $\begin{array}{l}\text { John Glenn College of Public } \\
\text { Affairs }\end{array}$ & $\begin{array}{l}\text { Course on food system planning and the economy } \\
\text { Minor in food policy }\end{array}$ \\
\hline $\begin{array}{l}\text { Knowlton School of } \\
\text { Architecture }\end{array}$ & $\begin{array}{l}2013 \text { symposium and exhibition for planning and design for } \\
\text { new urban food systems }\end{array}$ \\
\hline College of Arts and Sciences & $\begin{array}{l}\text { Translational plant sciences graduate program } \\
\text { Department of Theater lab series that includes Playing with } \\
\text { your food }\end{array}$ \\
\hline $\begin{array}{l}\text { The Center for Ethics and } \\
\text { Values }\end{array}$ & $\begin{array}{l}\text { University-wide COMPAS conversations that address issues } \\
\text { such as what it will take to feed an urbanized, climate- } \\
\text { challenged world }\end{array}$ \\
\hline College of Social Work & "Follow the Tomato" service-learning course \\
\hline Multiple Units & $\begin{array}{l}\text { Capstone project on local food and sustainable food } \\
\text { purchasing (in response to the university's sustainability } \\
\text { goals developed by the President and Provost's Council on } \\
\text { Sustainability in } 2015 \text {, which includes a goal of increasing } \\
\text { production and purchase of locally and sustainably sourced } \\
\text { food to } 40 \% \text { by 2025) } \\
\text { Food Fellows pilot program aimed to educate interdisciplinary } \\
\text { students about issues related to food, such as urban } \\
\text { agriculture, food policy, and food insecurity }\end{array}$ \\
\hline $\begin{array}{l}\text { International Studies and the } \\
\text { Office of International Affairs }\end{array}$ & $\begin{array}{l}\text { Multidisciplinary undergraduate courses such as food, } \\
\text { population, and the environment; and food security and } \\
\text { globalization. } \\
\text { Education abroad experiences such as South Africa's } \\
\text { sustainable agricultural system or European dairy science }\end{array}$ \\
\hline Student Life Center & $\begin{array}{l}\text { Thousands of students, faculty, staff, and community } \\
\text { members learn about diverse food and culture through the } \\
\text { annual Taste of OSU event hosted by international student } \\
\text { organizations. Additional emerging opportunities include } \\
\text { World Food Day, World Cities Day, and other United } \\
\text { Nations activities during Urban October. }\end{array}$ \\
\hline First Year Student Experience & $\begin{array}{l}\text { Buckeye Book Community brings together 7,000 incoming } \\
\text { freshman and members of the alumni association through } \\
\text { an author visit and community building dialogue integrated } \\
\text { into academic and co-curricular settings. In the 2015-16 } \\
\text { academic year, the featured book was The Good Food } \\
\text { Revolution. }\end{array}$ \\
\hline
\end{tabular}


OSU fosters collaborations to advance food system understanding for all, not just undergraduate and graduate students. The university extends learning with off-campus audiences through continuing education, workforce development, Extension, public media, and a P12 initiative to connect OSU personnel and students with school-aged children and their families. OSU faculty are involved in the World Food Prize and Global Youth Institute, a program for high school student leaders engaged in the global fight against hunger. Through television, radio, a blog, events, and online resources for educators and students, WOSU Public Media informs and inspires people across the state (http://wosu.org).

Extension faculty and staff improve communities by helping others learn (McGrath, Conway, \& Johnson, 2007). As an example in one community, food safety Extension education became an urgent priority after botulism killed one woman and hospitalized 24 others who had attended a church potluck. Extension also provides community nutrition education through a variety of curriculum for diverse audiences. To help Ohio citizens and community leaders learn about food systems, OSU Extension published "Healthy Food Systems," which is a guide to learn more about food production, food and business, food and health, and food and community. Leaders are also learners. One of the many ways leadership for a 21 st century food system is cultivated is through a national Food System Leadership Initiative (FSLI) program of the Association of Public and Land-Grant Universities (APLU) with support from the W. K. Kellogg Foundation (www.fsli.org). With OSU as a program partner and host for one of the three cohort sessions, university leaders focus on a holistic series of core leadership competencies of individual leadership; leading change within organizations; and understanding and influencing complex, diverse food systems.

\section{Food System Research and Innovation}

During the five-year period of this study, OSU continually ranked in the top 20 universities for total research expenditures (National Science Foundation) and research progressively developed through collaborative initiatives. With a total of $\$ 983$ million in annual research and development expenditures and 80 research centers across 16,000 acres, it's a challenge to adequately distinguish the percentage invested specifically in faculty-led food system research. There has been increasing investments through transdisciplinary discovery themes; food and agricultural research centers; and other innovations for economic, environmental, and social food system issues.

\section{Discovery Themes}

OSU's transdisciplinary Discovery Themes were launched in 2012 with the intent of bringing the full capacity of the university to address the world's most pressing challenges. This provided an unprecedented opportunity for the university to come together to find durable solutions to longterm targets such as Food Production and Security. The other broad areas of health and wellness; and energy and environment, also closely align with food system interests. Discovery Themes are funded, in part, through parking-lease payments. More than 140 new researchers are being 
hired in diverse fields, such as anthropology agriculture, architecture, nutrition, social work, public health, engineering, and economics. Faculty cluster or cohort hiring is an emerging practice as urban universities increasingly recognize interdisciplinary research and collaboration to address grand challenges facing society. OSU President Michael Drake, joined other Coalition of Urban Serving Universities presidents to share new research on faculty cluster hiring and a set of best practices to support the use of this strategy for improving faculty diversity and institutional climate.

\section{Food and Agricultural Research Centers}

A commitment to collaborative research has remained a core value at OSU, extending beyond formal initiatives such as the Discovery Themes. Food system research and innovation centers include:

- a vast network of agricultural experiment stations, some that have been around since 1887 as part of the Ohio Agricultural Research and Development Center (OARDC);

- the Food Industry Center, established in 1982 to improve food products and processes;

- the Center for Applied Plant Sciences, formed in 2012 to connect teams of investigators from many disciplines; and

- the Food Innovation Center (FIC), launched in 2010 to improve global quality of life by inspiring sustainable multi-disciplinary food solutions.

Teams launched by the FIC have involved 380 faculty members, staff, and graduate students with combined scholarly output that includes more than 60 peer-reviewed articles and more than 80 professional presentations. The initial $\$ 1.9$ million dollar investment in faculty research has resulted in almost $\$ 9$ million in extramural support. In 2013, the FIC funded an interdisciplinary team of researchers and community partners for a Mapping the Food Environment project to address the complex issues associated with food insecurity and health outcomes. In 2014, OSU's Center for Regional and Urban Analysis, the Local Food Council, the Kirwan Institute for the Study of Race and Ethnicity, and the John Glenn School of Public Affairs hosted a public listening session for individuals interested in working on mapping projects related to local food access. Many academic disciplines and community organizations use mapping to provide a visual representation of food systems, to explore the nuances of food environments, and to inform future research, including geography, planning, public policy, public health, human nutrition, and epidemiology (Sweeney et al., 2015).

The FIC also funds student innovations. For instance, Garden Express Meal Starters is a creation by students from food science and technology and human nutrition who shared an interest in combining good food science and social responsibility. They participated in the 2016 Food Fight competition sponsored by the Food Industry Center through an alliance with the Mid-Ohio Foodbank. Dehydrated underutilized vegetable medleys and spice packets create an appealing, affordable, long-lasting, nutritious sauce when combined with hot water. They are intended to be the base of a meal when paired with other foodbank products such as noodles, rice, meats, broths, or breads.

Innovation for Economic, Environmental, and Social Food System Issues 
For the economic aspect of food systems, the OSU Food Industries Center provides technical and scientific services to companies. The Department of Food Science and Technology, links education, research, and product development in fully equipped pilot plants. OSU's Center for Advanced Functional Foods Research and Entrepreneurship (CAFFRE) fuses expertise from food scientists, medical professionals, and policy experts that have experience working with industry partners. With a focus on "Crops to the Clinic to the Consumer," multidisciplinary research teams develop and enhance the availability of functional foods that promote health. One such product was black raspberry confections that have been used in clinical trials and sold at the Café at OSU's James Cancer Hospital. CAFFRE is one of several OSU centers for research.

From the environmental perspective, innovative food production is not enough for a sustainable food system. Between $25 \%$ and $40 \%$ of food grown, processed, or transported is wasted in the United States each year (Gunders, 2012). An OSU professor of Agricultural Marketing and Policy led a Food Waste Collaborative team to help solve America's food waste problem. The Collaborative faculty are conducting research to identify patterns regarding how Americans form attitudes on food waste and developing FoodImage, an app to measure food waste from food photos.

Social issues are also critical. Through Community Research Partners (CRP), OSU partners with the City of Columbus, United Way of Central Ohio, and the Franklin County Commissioners, to strengthen communities. Projects focus on topics such as food insecurity among college students, and food and nutrition as CRP partners in the Urban Institute's National Neighborhood Indicators Partnership. Ohioans are frequently involved with OSU research. More than 100 citizen-scientists are helping with a pollinator study conducted by the Department of Entomology at Ohio Agricultural Research and Development Center (OARDC).

These are just a few examples of OSU investments in creating collaborative and focused approaches for faculty and staff leaders to influence food systems through research and innovation. Findings are shared with the public through various methods and media, including University Communications and The Conversation, which was launched in 2014 as a multiinstitutional research reporting source. One example of an OSU faculty member sharing their knowledge with the public through The Conversation was a 2016 food security article authored by professors of anthropology and economics. Similar to other urban universities, OSU's food system research spans multiple disciplines and engages students, faculty, and industry. Unique aspects at OSU include the substantial investment in transdisciplinary team science and significant influence from the arts and vast medical center perspectives.

\section{Food System Outreach and Engagement}

Community-university partnerships have taken many forms and have been recognized as a valuable contribution to both the academic community and cities (Kotval, 2003). Establishing connections between university and community representatives enables research to contribute to social change in food systems work (Nelson \& Dodd, 2016; Rojas, Sipos, \& Valley, 2012; Tanaka \& Mooney, 2010). At OSU, an ever-emerging network of diverse partners involves faculty, staff, and students; local citizens and neighborhood groups; schools and libraries; public officials and agencies; private business and industry; non-profit organizations; and 
philanthropists. Engagement with these diverse collaborators has helped inform and shape OSU's food system teaching, research, and stewardship. In 2016, the Association of Public and Land-grant Universities (APLU) released a framework for the New Engagement, specifically recognizing unique dynamics for universities situated in large metropolitan areas. For urban universities, diversity in the community and on campus presents a unique context. With the size and scope of the university and the city, engagement can sometimes be daunting. Engaging diverse stakeholders is not always easy, especially when addressing the many issues surrounding food. Food system definitions and expectations vary based of the perspective of academic disciplines, the focus of government agencies, the mission of non-profit organizations, industry agendas, geographic scope, grassroots citizen priorities, and cultural influence. Competing interests and tensions are common within various aspects of the food system (Campbell, 2004; Levkoe, et al., 2016).

OSU has a long history of outreach and engagement (Bromley \& Kent, 2006). Working collaboratively is an increasing focus through OSU's Office of Outreach and Engagement, the university's extensive statewide Extension network, and a College Engagement Council that connects college deans from all OSU campuses. Engagement is cultivated through individual food system projects, interdisciplinary centers, and at university-wide events. OSU earned the Carnegie Foundation for the Advancement of Teaching's 2015 Community Engagement Classification, acknowledging the university's extensive engagement and recognizing OSU's mission, culture, curriculum and resources are structured to support high-impact community engagement.

An example of extensive community engagement was the 2016 Buckeye Summit that convened approximately 600 members of "Buckeye Nation" to address food security. Additional local events involved some of OSU's 530,000 alumni members, corporate partner personnel, and other members of the community. Other engagement efforts include Campus Partners for Community Urban Redevelopment, an interdisciplinary center established by OSU in cooperation with the City of Columbus to spearhead the revitalization of the University District. Specific projects also engage the local community. For example, in 2013-14, multiple OSU units joined citizens and community groups to explore how food could be a catalyst for urban neighborhood development. Ongoing engagement opportunities can be found through volunteer.osu.edu, where community members, fans, and friends, alumni, and faculty can get involved with OSU through a wide variety of commitments. Food touches everything and is a foundation of an endlessly evolving enactment of individual and community relationships (Counihan \& Van Esterik, 2013).

\section{Student Engagement}

Student engagement in higher education is a complex construct influencing the student experience and student success (Kahu, 2013). Students get involved with the community through internships, service learning, and other activities. A food system example is the Buckeye Food Alliance food pantry, established by roommates and friends to improve food security on campus. OSU students interested in social transformation can apply for the OSU President's Prize, which provides two graduating seniors with vital connections and financial support to advance innovative ideas for change in their first year after graduation. One of the OSU students who won a 2016 President's Prize received \$100,000 to create an Ohio State community garden to 
provide produce to local food insecure families. Another example of OSU student engagement is Pay It Forward, an OSU student cohort to help students become lifelong, civically-engaged citizens.

\section{Faculty Engagement}

Faculty connections to food systems extend beyond classrooms, laboratories, and formal channels of engaged scholarship. Faculty engage in food system activities, from direct community service to participating in community dialogue involving diverse, and sometimes competing values. The John Glenn College of Public Affairs fosters networking for the representatives of Ohio's food policy councils. In 2013, OSU professors served as panelists for a public conversation on food, farming, and the social, economic, environmental, and emotional aspects of biotechnology (GMOs) and sustainability. In 2014, faculty with OSU's Center for the Study of Religion joined others in a presentation series, "Everybody Eats: Exploring Food, Flavors, and Faith." As faculty participate in on- and off-campus activities, it's essential for them to understand academic freedom and responsibility that differentiate between official activities as faculty and personal activities as citizens.

\section{OSU Extension}

With offices in all of Ohio's 88 counties, Extension connects with urban universities throughout the state and across the nation. Wide-spread interest in food and farming creates an opportunity for Extension to provide leadership and expertise (Sharp, Clark, Davis, \& Bean Smith, 2011). For example, OSU Extension in Cuyahoga County is a co-convener of the Cleveland-Cuyahoga County Food Policy Coalition. Nationally, Extension professionals, working on community food systems, have collaborated through the eXtension Community of Practice (https://extension.org), Joint Council of Extension Professionals, and Healthy Food Systems, Healthy People, a collaboration of the Association of Public and Land-Grant Universities. Extension educators set the stage for stable relationships, inter-organizational linkages, and feedback loops upon which localized food systems could be built (Dunning et al., 2012; Gulati \& Gargiulo, 1999; Ramasawmy \& Fort, 2011; Sundkvist, Milestad, \& Jansson, 2005). OSU Extension provides leadership for statewide food hubs, farmers markets, and the Ohio Farm to School program.

\section{Philanthropy}

Philanthopy is another way alumni and friends are engaged as OSU tackles complex global problems related to food production and security. In 2016, a \$5 million gift from an individual donor was the first contribution toward transforming the 261-acre Waterman Farm on campus into a more comprehensive research, learning, and outreach hub for the study of urban agriculture, food security, and food systems. OSU's Garden of Hope, also located on the Waterman farm, helps cancer survivors and their caregivers understand links between health, nutrition, and the cancer-fighting properties of freshly grown fruits and vegetables. Communityuniversity engagement is frequently evident in fundraisers that feature local foods and raise money to advance food system projects. In 2011, one week before the annual OSU football game against the rival team up north, the two schools participated in a different kind of match-up as top chefs from each school engaged in an Earth to Table sold-out dinner competition to support 
the Culinary Vegetable Institute's educational efforts with local schools. Gifts and grants from corporations, foundations, and individuals are vital to OSU's focus on food systems.

\section{Food System Resource Stewardship}

Similar to other urban universities, creating a campus culture that embraces sustainability, communicates its benefits, and rewards innovation is a key initiative at OSU. Sustainable food systems are an integral part of stewardship developments (Barlett, 2011). OSU participates in a network of higher education presidents committed to climate change and sustainability actions (http://secondnature.org). At OSU, the President and Provost's Council on Sustainability advises and oversees the integration of sustainable practices, programs, and projects.

One of OSU's sustainability goals is to increase production and sales of locally and sustainably sourced food to $40 \%$ by 2025 . This is a significant commitment, as the university serves 40,000 daily meals to diverse individuals interested in sustainably sourced, healthy, affordable, safe, delicious, culturally appropriate food that meets a range of food preferences and allergies. OSU's total annual food budget includes student dining, medicine, and event hospitality. As one of many large food purchasers, attention is also directed toward impacts in the larger community. Excess food at OSU is repurposed for use at a later date, donated to foodbanks, or turned into pulp to be used for renewable energy. In 2013, OSU conducted an assessment of waste and recycling materials, which resulted in an expanded organics diversion program and a goal of achieving zero food waste by 2025 . Additional programs to donate food include a program created by the undergraduate student government, which allows students to take unused dining service credits in the last two weeks of each semester to buy non-perishable food to benefit Neighborhood Services.

Students have been actively engaged in OSU's food sourcing sustainability goal through shared governance, student life activities, a capstone course, research, and activism. Research included a thesis on analyzing OSU's food purchasing system (Kingston, 2015). Student interest in food purchasing escalated into discontent and unrest, becoming apparent in \#ReclaimOSU. Disputes over definitions led to a 2015 student sit-in, demanding the university president sign the Real Food Campus Commitment. In 2016, students advocating for improvements in the university's food system won $\$ 5,000$ through Plate of the Union, a national grass-roots campaign calling for reforms to the nation's food system. Real Food OSU co-hosted a teach-in with Defend Our Future and several other student organizations.

OSU administrators, faculty, staff, and student organizations continue to find common ground on definitions and practices that meet OSU's sustainable goals, student expectations, and multiple stakeholder agendas. Food system developments and sustainability practices are influenced through OSU's shared governance of the University Senate. Universities need collaborative agents of change (Bradshaw \& Fredette, 2009) and shared governance in higher education decreases conflict (Delbecq, Bryson, \& Van de Ven, 2013). From the board of trustees to administrators, professors, dining services, and students, most university stakeholders commit to food system stewardship. Complexities arise due to diverse sustainability meanings and measures. OSU's especially ambitious sustainability goals related to food purchasing and food waste challenge everyone involved in the university food system. A unique aspect at OSU is the 
involvement of shared governance through the university senate, which includes faculty, administration, and student representatives.

\section{Conclusion}

Food systems will remain a challenge as the world's population continues to move to urban areas and grow to the projected 9.7 billion by 2050 (http://www.un.org). As food demands increase by 60 percent, urban university administrators, faculty, staff, students, alumni, partners, and other friends need to continue finding common ground for a sustainable future. As a land-grant, urbanserving, Carnegie-engaged, research university, OSU has a moral and civic obligation to engage in important issues on local, national, and international levels. Key lessons learned through this study include the dynamics of a collective approach and the value of leadership.

\section{Dynamics of a Collective Approach}

OSU's collective food systems approach aligns with the university's mission, vision, values, and goals (see Figure 2). Progress is evident across the university as collaborators address the complexities of this grand challenge. This case study presents what was common and what was particular to OSU's collective approach to food system issues. Most notably, were the strategic resource investments to collectively address complex food systems and the inclusion of advancement, alumni, and other perspectives. 


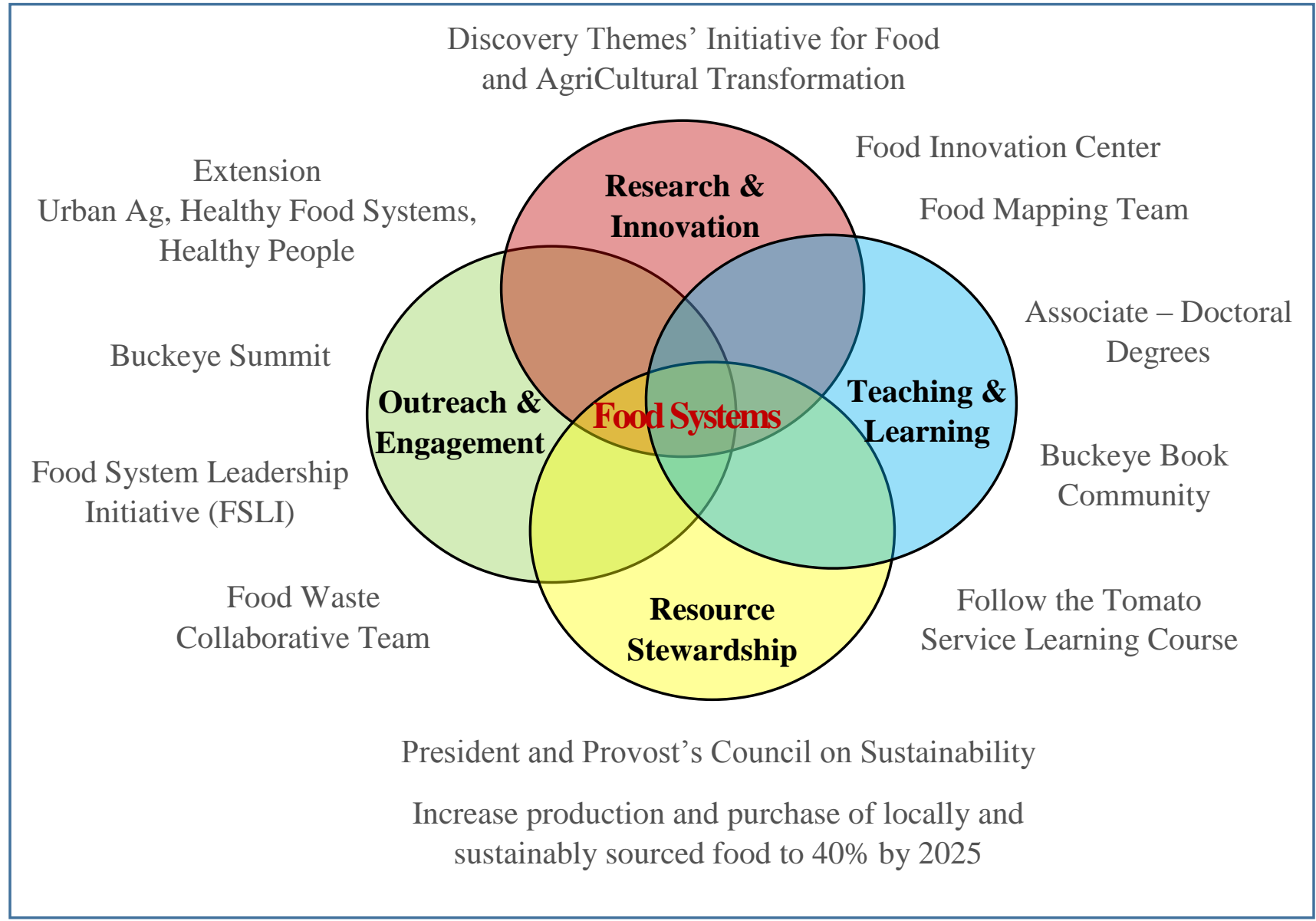

Figure 2. Examples of OSU's Collective Approach to Food Systems-Align with the University's Mission. OSU is exploring ways to capture and communicate shared impacts. Many of the intentional collaborative efforts have been established in the past 10 years. Discovery Themes, for example, are still in early stages of development as new faculty test transformative approaches for food system teaching, research, and engagement. Impact reporting will play an essential role in future investments.

Value of Leadership

Food system leadership begins at the highest levels and is strengthened by the collaborative commitment of diverse stakeholders. Urban universities are being approached by students, neighborhoods, city and county governments, and others to play an increasingly active role in addressing complex challenges of urban revitalization (Sterrett, 2009). Food systems enmesh linkages between metropolitan cities and rural countryside, with movement of people, goods, capital, and other social transactions, which influences rural and urban change (Tacoli, 1998). Urban universities can boldly lead divergent discourse on the multiple dimensions of food systems. Leaders at all levels can advance food systems by asking questions for inclusive dialogue, leveraging unique urban university assets, respecting the distinct role of public and private interests, and recognizing the interdependencies of urban and rural; local and global; and conventional and alternative. OSU food system stakeholders can continue to learn with other 
urban leaders, such as the National League of Cities, and Food and Agriculture Organization (FAO) of the United Nation's "Food for Cities," a community of practice with more than 2,500 members from 114 countries connecting research and practice on sustainable food systems and urbanization. Food system leadership has deliberately been developed through projects such as the Food System Leadership Initiative and the cultivation of systems leaders through the Sustainable Food Lab global network, but there is tremendous opportunity to bring an urban focus and collective approach to food system leadership development. Urban university leaders can make significant collective impact by uniting. Many urban serving universities share a commitment to food systems and food security. Universities can benefit from collaborating with one another to leverage unique assets and account for specific limitations of each institution.

Shared commitment, collective resources and diverse perspectives ensure that strategic priorities will continue to advance, even in the face of inevitable obstacles. During the five-year period of this study, the emphasis on transdisciplinary food system impacts has engaged multiple contributors to make significant developments. Additional discoveries will emerge as urban universities continue to explore a strategic shift from individual projects to a more collective approach to complex food system issues and opportunities.

\section{References}

Barlett, P. F. (2011). Campus sustainable food projects: critique and engagement. American anthropologist, 113(1), 101-115. https://doi.org/10.2307/3343472

Bradshaw, P. and Fredette, C. (2009), "Academic governance of universities: reflections of a senate chair on moving from theory to practice and back", Journal of Management Inquiry, 18(2), 123-133. https://doi.org/10.1177/1056492608326320

Bromley, R., \& Kent, R. B. (2006). Integrating beyond the campus: Ohio's urban public universities and neighborhood revitalization. Planning, Practice \& Research 21(1), 45-78. https://doi.org/10.1080/02697450600901517

Campbell, M. (2004). Building a common table: The role for planning in community food systems. Journal of Planning Education and Research, 23 (4): 341-55.

https://doi.org/10.1177/0739456X04264916

Counihan, C., \& Van Esterik, P. (2013). Why food? Why culture? Why now? Introduction to the third edition. Food and culture: a reader, 1-15. New York: Routledge.

Creswell, J. W. (2013). Qualitative inquiry and research design: Choosing among five approaches. Los Angeles, CA: Sage.

Delbecq, A. L., Bryson, J. M., \& Van de Ven, A. H. (2013). University Governance Lessons From an Innovative Design for Collaboration. Journal of Management Inquiry, 22(4), 382-392. https://doi.org/10.1177/1056492612471996 
Dunning, R., Creamer, N., Massey Lelekacs, J., O’Sullivan, J., Thraves, T., \& Wymore, T. (2012). Educator and institutional entrepreneur: Cooperative Extension and the building of localized food systems. Journal of Agriculture, Food Systems, and Community Development, 3(1), 99-112. https://doi.org/10.5304/jafscd.2012.031.010

Fauvel, A. M., \& Lake, D. L. (2015). Tackling Wicked Food Issues: Applying the Wicked Problems Approach in Higher Education to Promote Healthy Eating Habits in American School Children.

Golden, S. (2013). Urban agriculture impacts: Social, health, and economic: A literature review. Agricultural Sustainability Institute at University of California Davis.

Gulati, R., \& Gargiulo, M. (1999). Where do interorganizational networks come from? American journal of sociology, 104(5), 1439-1493. https://doi.org/10.1086/210179

Gunders, D. (2012). Wasted: How America is losing up to 40 percent of its food from farm to fork to landfill.(NRDC Issue Paper IP:12-06-B) Retrieved from Natural Resources Defense Council Website: http://www.nrdc.org/issues/food-waste

Hackett, S., \& Parmanto, B. (2005). A longitudinal evaluation of accessibility: higher education web sites. Internet Research, 15(3), 281-294. https://doi.org/10.1108/10662240510602690

Hamm, M., \& Bellows, A. (2003). Community Food Security and Nutrition Educators. Society for Nutrition Education 35(1): 37-43. https://doi.org/10.1016/S1499-4046(06)60325-4

Hartley, J. F. 1994. Case studies in organizational research. In C. Cassell and G. Symon (Eds.) Qualitative methods in organizational research: A practical guide, (pp. 209-29). London: Sage.

Kahu, E. R. (2013). Framing student engagement in higher education. Studies in higher education, 38(5), 758-773. https://doi.org/10.1080/03075079.2011.598505

Kington, L. (2015). Analyzing Ohio State University’s Food Purchasing System: Opportunities for Change through the Real Food Challenge.

Koc, M. (1999). For hunger-proof cities: Sustainable urban food systems. IDRC.

Kotval, Z. (2003). University Extension and Urban Planning Programs: An Efficient Partnership. Journal of Extension [Online], 41(1) Article 1FEA3. Retrieved from http://www.joe.org/joe/2003february/a3.php

Lang, T., \& Heasman, M. (2015). Food wars: The global battle for mouths, minds and markets. New York: Routledge.

Lauckner, H., Paterson, M., \& Krupa, T. (2012 March 26). Using constructivist case study methodology to understand community development processes: Proposed methodological questions to guide the research process. The qualitative report, 17(13), 1. 
Levkoe, C. Z., Andrée, P., Bhatt, V., Brynne, A., Davison, K. M., Kneen, C., \& Nelson, E. (2016). Collaboration for Transformation: Community-Campus Engagement for Just and Sustainable Food Systems. Journal of Higher Education Outreach and Engagement 20(3), 3261.

Mcgirr, H. K., \& Batterbury, S. P. (2016). Food in the City: Urban Food Geographies and 'Local' Food Sourcing in Melbourne and San Diego County. Geographical Research, 54(1), 318. https://doi.org/10.1111/1745-5871.12156

McGrath, D., Conway, F., \& Johnson, S. (2007). The Extension hedgehog. Journal of Extension, 45(2) Article 2FEA1. Retrieved from www.joe.org/joe/2007april/a1.php

Merriam, S. B. (1988). Case study research in education: A qualitative approach. Jossey-Bass.

Murphy, J., Hashim, N. H., \& O'Connor, P. (2007). Take me back: validating the Wayback Machine. Journal of Computer-Mediated Communication, 13(1), 60-75. https://doi.org/10.1111/j.1083-6101.2007.00386.x

Nelson, E., \& Dodd, W. (2016). Collaborating for community food security: Emerging scholar participation in a community-university partnership. Action Research 0(0). https://doi.org/10.1177/1476750316656041

Pothukuchi, K., \& Kaufman, J. L. (1999). Placing the food system on the urban agenda: The role of municipal institutions in food systems planning. Agriculture and Human Values 16(2), 213224. https://doi.org/10.1023/A:1007558805953

Pothukuchi, K., \& Molnar, S. A. (2015). Sustainable Food Systems At Urban Public Universities: A Survey Of U-21 Universities. Journal of Urban Affairs 37(3), 341-359. https://dx.doi.org/10.1111/juaf.12149

Ramasawmy, B., \& Fort, F. (2011). Can innovation be institutionally-driven? The case of institutional entrepreneurs in the restructuration of the Mauritian vegetable supply chain. 6th Proceedings of the European Conference on Innovation and Entrepreneurship. Retrieved from http://www.academic-conferences.org/pdfs/ecie_2011_best_phd.pdf

Rojas, A., Sipos, Y., \& Valley, W. (2012). Reflection on 10 years of community-engaged scholarship in the Faculty of Land and Food Systems at the University of British ColumbiaVancouver. Journal of Higher Education Outreach and Engagement, 16(1), 195-214.

Sharp, J.S., Clark, J.K., Davis, G.A., \& Bean Smith, M. (2011). Adapting community and economic development tools to the study of local foods: The case of Knox County, Ohio. Journal of Extension, 49(2), 1-12. Article 2FEA4. Retrieved from http://www.joe.org/joe/2011april/a4.php

Stake, R. E. (1995). The art of case study research. Thousand Oaks: Sage Publications. 
Sterrett, S. A. (2009). Planning and partnerships for the renewal of urban neighborhoods. Journal of Higher Education Outreach and Engagement, 13(3), 113-130.

Sundkvist, A., Milestad, R., \& Jansson, A. M. (2005). On the importance of tightening feedback loops for sustainable development of food systems. Food Policy, 30(2), 224-239. https://doi.org/10.1016/j.foodpol.2005.02.003

Sweeney, G., Hand, M., Kaiser, M., Clark, J. K., Rogers, C., \& Spees, C. (2015). The State of Food Mapping Academic Literature Since 2008 and Review of Online GIS-based Food Mapping Resources. Journal of Planning Literature 31(2), 123-219. https://dx.doi.org/10.1177/0885412215599425

Tacoli, Cecilia. (1998). Rural-urban interactions: a guide to the literature. Environment and Urbanization, 10(1), 147-166. https://doi.org/10.1177/095624789801000105

Tanaka, K., \& Mooney, P. H. (2010). Public scholarship and community engagement in building community food security: The case of the University of Kentucky. Rural Sociology, 75(4), 560583. https://doi.org/10.1111/j.1549-0831.2010.00029.x

Thelwall, M., \& Wilkinson, D. (2003). Three target document range metrics for university Web sites. Journal of the American Society for Information Science and Technology, 54(6), 490-497. https://doi.org/10.1002/asi.10222

Yin, R. K. (2011). Applications of case study research. New York: Sage Publications. 


\section{Author Information}

Julie Fox, Ph.D., is an Associate Professor with the Ohio State University (OSU) College of Food, Agricultural \& Environmental Sciences and serves as an Associate Chair for the Department of Extension, leading OSU Extension in the City. She is part of OSU's leadership group focused on OSU's urban influence and mission. She has worked with OSU since 1998 and began focusing on food system research, education, and service.

Julie M. Fox, Ph.D.

Department of Extension

College of Food, Agricultural and Environmental Sciences

The Ohio State University

2120 Fyffe Road, Suite $25 \mathrm{~N}$

Columbus, OH 43210-1002

E-mail: fox.264@osu.edu

Telephone: 614-292-0456

http://u.osu.edu/juliefox

https://twitter.com/foxosu

https://www.linkedin.com/in/julie-fox-208a7210

\section{Appendix}

Documents from the following resources were reviewed and coded for content in one or more of the following categories: teaching and learning; research and innovation; outreach and engagement; and resource stewardship.

Agricultural Technical Institute, https://ati.osu.edu Agroecosystems Management Program, http://amp.osu.edu Association of Public and Land-grant Universities (APLU), Engagement and Outreach, http://www.aplu.org/members/councils/engagement-and-outreach

Buckeye Book Community, https://fye.osu.edu/bbc.html

Buckeye Food Alliance food pantry, http://www.buckeyefoodalliance.org

Buckeye Summit, https://buckeyesummit.osu.edu

Campus Partners for Community Urban Redevelopment, http://campuspartners.osu.edu

Carnegie Classification of Institutions of Higher Education, http://carnegieclassifications.iu.edu

Carnegie Foundation for the Advancement of Teaching's 2015 Community Engagement

Classification, www.carnegiefoundation.org

Center for Advanced Functional Foods Research and Entrepreneurship (CAFFRE), https://u.osu.edu/caffre/food-centers

Center for Ethics and Values, https://cehv.osu.edu

Coalition of Urban and Metropolitan Universities (CUMU), http://www.cumuonline.org

College of Arts and Sciences https://artsandsciences.osu.edu

College of Food, Agricultural, and Environmental Sciences, http://cfaes.osu.edu

Community Research Partners, www.communityresearchpartners.org

The Conversation (food security article), https://theconversation.com/u-s-is-a-land-of-plenty-sowhy-do-millions-of-americans-still-go-hungry-55791

Department of Food Science and Technology, http://fst.osu.edu 
Discovery Themes, https://discovery.osu.edu

Everybody Eats: Exploring Food, Flavors, and Faith, https://religion.osu.edu/events/food-familyand-faith-soup-nuts-abrahamic-traditions.-kickoff-series-everybody-eats-exploring

Extension, http://extension.osu.edu

Faculty Cluster Hiring Report, Urban Serving Universities, http://usucoalition.org/images/Faculty_Cluster_Hiring_Report.pdf

Food and Agriculture Organization of the United Nation's "Food for Cities," http://www.fao.org/fcit/en

Food Fellows, https://u.osu.edu/foodfellows/home

Food Industry Center, http://foodindustries.osu.edu

Food Initiative, www.osu.edu/initiatives/food.html

Food Innovation Center, http://fic.osu.edu

Food System Leadership Initiative, www.fsli.org

Food Waste Collaborative, https://u.osu.edu/foodwaste

Garden of Hope, https://cancer.osu.edu/blog/garden-of-hope-offers-survivors-wholesomecancer-fighting-foods

Healthy Food Systems, Healthy People, http://www.aplu.org/projects-and-initiatives/agriculturehuman-sciences-and-natural-resources/healthy-food-systems-healthy-people

Internet archive, Wayback Machine, www.archive.org

John Glenn College of Public Affairs (food policy), http://glenn.osu.edu/research/food-policy

Joint Council of Extension Professionals, http://jcep.org

Knowledge Bank (Local and Sustainable Food Purchasing at The Ohio State University: Capstone Course Proposal), http://kb.osu.edu/dspace/handle/1811/76746

Knowlton School of Architecture, http://knowlton.osu.edu

Living Culture Initiative, https://u.osu.edu/livingculture

Local Food Action Plan, https://www.columbus.gov/publichealth/programs/Local-Food-Action$\underline{\text { Plan }}$

Mapping the Food Environment, http://foodmapping.osu.edu

National League of Cities, http://www.sustainablecitiesinstitute.org

National Science Foundation, Rankings by total R\&D expenditure, https://ncsesdata.nsf.gov/profiles/site?method=rankingBySource\&ds=herd

New Engagement: Exploring the Issues Across a Spectrum, http://www.aplu.org/library/thenew-engagement-exploring-the-issues-across-a-spectrum/file

Office of Academic Affairs, https://oaa.osu.edu

Office of International Affairs, https://oia.osu.edu

Office of Research, http://research.osu.edu

Ohio Agricultural Research and Development Center, http://oardc.osu.edu

Ohio Campus Compact statewide non-profit coalition of 41 college and university presidents and their campuses, http://www.ohiocampuscompact.org

Ohio Farm to School program, http://farmtoschool.osu.edu

Outreach and Engagement, http://outreach.osu.edu

Pay It Forward OSU student cohort, http://payitforward.osu.edu

P12 initiative, http://p12.ehe.osu.edu

Plate of the Union, www.plateoftheunion.com

President and Provost's Council on Sustainability, https://president.osu.edu/leadership-andcommittees/president-and-provosts-council-on-sustainability.html 
President Drake's Vision 2020, www.osu.edu/features/2015/2020-vision.html

President's Prize, President's Prize, https://presidentsprize.osu.edu

Real Food Challenge, www.realfoodchallenge.org

Real Food OSU, https://www.facebook.com/RealFoodOSU

Student Life Center, http://studentlife.osu.edu

Sustainable Food Lab, http://www.sustainablefoodlab.org

Targeted Investments in Excellence (2006 - 2011) https://oaa.osu.edu/tie.html

Technology Commercialization Office, https://tco.osu.edu

University Communications, https://researchnews.osu.edu

University Senate, http://senate.osu.edu

University Vision and Mission 2016, https://oaa.osu.edu/vision-mission-values-goals.html

Urban Institute's National Neighborhood Indicators Partnership,

www.neighborhoodindicators.org

Urban October, http://www.urbanoctober.org

Urban Universities for Health (cluster hiring), http://usucoalition.org/images/Faculty_Cluster_Hiring_Report.pdf

Student organizations, http://www.ohiounion.osu.edu/get_involved/student_organizations

World Food Prize, https://www.worldfoodprize.org

WOSU Public Media, http://wosu.org 